\title{
Ranonovovjekovna melioracija, protomoderne migracije i ekonomski razvoj vranskog posjeda
}

DOI: https://doi.org/10.11567/met.33.1.2 UDK: 314 (497.5-3Dalmacija-17)"16/17" 631.6(497.5-3Dalmacija-17)"16/17" Izvorni znanstveni rad Primljeno: 14.02.2017. Prihvaćeno: 05.06.2017.

\author{
Dubravka Mlinarić
}

Institut za migracije i narodnosti, Zagreb

dubravka.mlinaric@imin.hr

Drago Župarić-Iljić

Institut za migracije i narodnosti, Zagreb

drago.zuparic@imin.hr

\section{SAŽETAK}

U radu se autori fokusiraju na lokalne i prekogranične migracijske procese u sjevernoj Dalmaciji i njihov utjecaj na razvoj vranskog feuda tijekom 17. i 18. stoljeća. Nakon kvalitativne analize demografske, crkvene i kartografske arhivske građe uspostavljena je veza između ekonomskih i okolišnih procesa i razvoja u nizinskome močvarnom pograničju, u odnosu spram prirodne osnove, geostrateške pozicije te komunikacijsko-komercijalnoga i (i)migracijskog potencijala prostora. U radu se pokušava odgovoriti i na pitanje je li se privatni pothvat melioracije posjeda obitelji Borelli pokazao ekonomski uspješnim ili pak avanturističkim eksperimentom u okolnostima neuspješne sesilizacije doseljenog stanovništva iz Bukovice. Pritom protomoderne lokalne migracije Morlaka rezultiraju njihovim angažmanom na isušivanju močvara i blata, uz već postojeću ulogu u obrani Novoga i Najnovijega mletačkog posjeda od eventualnih ponovnih osmanskih upada. Iako njihovo doseljavanje nema okolišni predznak, u konačnici su oni melioracijom izmijenili okoliš Kotara, usprkos činjenici da je ratarska ekonomska eksploatacija ostala nerazvijena, dok je prevladavajuće stočarenje na plodnoj i melioriranoj zemlji predstavljalo ekonomski neracionalno iskorištavanje zemlje. Način na koji je ravnokotarski kraj demografski, pa i ekonomski profitirao od redistribucija stanovništva iz zaleđa dio je odgovora na demografsku devastaciju izazvanu osmanskim ratovima početkom ranoga novog vijeka, pustošenjem te okolišnim pritiskom na močvarno zemljište nakon mletačke rekonkviste. Nizinski je okoliš izmijenjen melioriranjem zapuštenih vodotoka, čime je čovjek ponovno, prvi put nakon antike, intenzivnije zadirao u okoliš. Ishod toga ranonovovjekovnog sraza ekonomskih i okolišnih interesa na ograničenom prostoru vranskog feuda rezultirao je značajnim razlikama u kvaliteti i predznaku razvoja u kratkoročnoj u odnosu na dugoročnu perspektivu.

KLJUČNE RIJEČI: migracije, Rani novi vijek, melioracija, okoliš, sjeverna Dalmacija, ekonomski razvoj, demografski razvoj 
Usporedba ranonovovjekovnih ekonomskih i okolišnih procesa, posebno ako je riječ o pograničnom, politički i ekološki nestabilnom prostoru, kao što su to bile vranske močvare i blata u 18. stoljeću, složen je istraživački izazov koji nužno iziskuje interdisciplinarni komparativno-analitički pristup izučavanju okolišne povijesti s naglaskom na ekohistorijskoj perspektivi. Tim više ako se, uz prirodnu osnovu kao povijesnu datost, geostratešku poziciju kao ranonovovjekovnu okolnost te komunikacijsko-komercijalnu važnost najvećega dalmatinskog feuda, u obzir uzme i njegov migracijski potencijal. Stoga je jedan od primarnih ciljeva rada analizirati utjecaj lokalnih i prekograničnih migracijskih procesa u sjevernoj i srednjoj Dalmaciji na razvoj vranskog feuda tijekom 17 . i 18. stoljeća.

\section{IZVORI,METODOLOGIJA, CILJEVI}

Na temelju kvalitativne analize arhivskog materijala demografske, ekonomske, lingvističke i kartografske provenijencije, uspoređene s dostupnim istraživanjima sličnih fenomena iz sekundarne literature, rekonstruirani su temeljni migracijski pravci, pa čak i procijenjeni njihova učestalost odnosno intenzitet te učinci na isušivanje močvara na prostoru istočnog dijela Ravnih kotara (Donji kotar Zadarskoga okružja), kao i privođenje tla gospodarskim kulturama. ${ }^{1}$ Genealoška stabla sela na feudu u obliku deskriptivnih kumulativnih bilješki dokumentiraju kretanje broja stanovnika u obiteljima prvoinvestiranoga člana obitelji tijekom druge polovine 18. i prve 19. stoljeća. Paradigmatsko naselje koje se nalazilo kraj same močvare za ovo je istraživanje naselje Tinj, ${ }^{2}$ za koji je rekonstruirana migracijska mreža na onodobnoj karti. ${ }^{3}$ Ona je jednim dijelom bila uzrokovana melioracijskim radovima na posjedima sela, a drugim omogućivala daljnju melioraciju odnosno čovjekom induciranu modifikaciju okoliša (slika 1). Budući da je čovjekov napredak i neovisno o modernim tehnologijama donekle ugrožavao i prirodu, bilo u smjeru neodrživoga ili prekomjernoga kultiviranja ili npr. ratne destrukcije pejzaža, razmotrit ćemo kako su osmansko-mletački rato-

Tematika vranskog feuda pod mletačkom upravom, s posebnim naglaskom na malarične bolesti i provedbu melioracije, mnogo je detaljnije analizirana u doktorskoj disertaciji Dubravke Mlinarić Mal'aria i socio-migracijska kretanja u sjevernoj Dalmaciji u 18. stoljeću (str. 307-325), obranjenoj na Filozofskom fakultetu 2004.; usp. Mlinarić, 2006a, 2006b.

2 Analizirani izvori nalaze se u Državnom arhivu u Zadru pod oznakom: HR-DAZD-348. Obitelj Borelli-Galbiani (u nastavku OBG), svežanj 98, stanovništvo feuda, Albero Genealogico di Tign, br. 72/ 1-30.

3 Kao predložak je poslužio isječak karte zapadnog dijela Mletačke Dalmacije P. Santinija iz 1780. (Nouvelle carte de la partie occidentale de Dalmatie), NSK, Zbirka starih karata i atlasa, SJ-Z-XVIII-18. 
vi i kolonizacija Morlaka iz zaleđa, a potom i melioracija močvara na sredozemnome krškom feudu obitelji Borelli, pridonosili drugim, manje ili više trajnim promjenama u okolišu. Upravo je ekohistorijska paradigma važna za ovakvu vrstu istraživanja jer ta poddisciplina unosi povijesnu dimenziju u proučavanje okoliša, odnosno potencira važnost prožetosti i interakcije prirodnog i društvenog okoliša sa samim ljudskim društvom, u svim njihovim mijenama i uzajamnostima od početaka ljudskog roda, preko razdoblja drevnih civilizacija do današnjeg doba postmoderne (Delort i Walter, 2002: 8). Braudel je okoliš i klimu smatrao, između ostaloga, jednim od bitnih temelja i uvjeta civilizacija kao »strukture dugog trajanja (Braudel, 1990: 43). Suvremeni povjesničari okoliša (ekohistoričari) Delort i Walter (2002: 4) podsjećaju da je riječ »okoliš« ušla u upotrebu u područje ekologije sedamdesetih godina 20. stoljeća, temeljeći se na starijoj francuskoj riječi environnement, koja je označivala »ono što okružuje neki živi organizam«. Ekohistorija je znanstvena disciplina pogodna i za proučavanje predmodernih migracija, koje mogu biti uvjetovane izravnim ili posrednim utjecajem promjena u okolišu (Delort i Walter, 2002; McNeill, 2003; Diamond, 2005). Ona ponekad $\mathrm{u}$ fokus istraživačkog interesa stavlja i uvjete nastanka i širenja bolesti te epidemija, poput kuge u srednjem vijeku ili u ranome novom vijeku endemične malarije ustaljene u okolišu zadarskog zaleđa.

Premda su motivi spomenutih migracijskih kretanja u sjevernoj Dalmaciji bili raznoliki, a izvori o njima lapidarni, pa čak i interpretacijski spekulativni, nastojali smo strukturirati osnovne tipove prostorne mobilnosti. Riječ je o protomodernim odnosno predmodernim migracijama, promatranim unutar okvira teorije migracija, a ne u okvirima vremenske etape ranoga novog vijeka (engl. Early Modern period), zbog čega smo i odabrali prvi termin. Tako postavljen cilj realno je dosežan odabirom komparativne i analitičke metodologije koja omogućuje temeljitije zahvaćanje u povijest okoliša i njegovih mijena. Značenje pojma okolišnih migracija koji se upotrebljava u historiografiji preispitano je na primjeru morlačkog doseljavanja na vranski feud kao posebnog oblika lokalnih, ali ujedno i prekograničnih migracija vlaškoga (morlačkog) stanovništva, zabilježenih prije vođenja sustavnih službenih statistika. Ono se preseljavalo spletom različitih uzroka i poticaja, među kojima je okolišna komponenta, u ovom slučaju potreba za melioracijom močvarnoga vranskog feuda, bila sporedna. Naime pokazalo se da morlačke migracije iz Bukovice nisu imale dominantan utjecaj na stanje i promjene okoliša $u$ inicijalnoj fazi doseljavanja premda su posljedice nove distribucije stanovništva i u ekonomskom i u ekološkom smislu ostavile znatan otisak u pejzažu. 


\section{GEOSTRATEŠKA VAŽNOST VRANSKOG POSJEDA U OKOLNOSTIMA PROTUOSMANSKIH RATOVA}

Evidentno su presudnu ulogu na ekonomski, a potom i demografski razvoj posjeda imali njegova geostrateška pozicija na mletačko-osmanskom pograničju odnosno mehanizmi rješavanja sukobâ u zoni razgraničenja utjecaja Venecije, Osmanlija, a rubno i Habsburgovaca. Tim više jer je plodan prostor bogat humusom i pitkom vodom još od antike funkcionirao kao plodna žitnica i gusto naseljen kraj. Svjedoče to nalazi čak 41 rimskog objekta, od čega je 35 bilo gospodarskih imanja (villae rusticae), ali i objekata vojne namjene ili kupališta u Tinju i Polači (Nedved, 1990: 213-245). Značajna gospodarska i stambena aktivnost temeljila se na opskrbi hranom i vodom, čemu svjedoči i provedeni akvadukt od izvora Bibe do Jadera. ${ }^{4}$ Čovjek je očito uspio ukrotiti prirodu i antropizirati specifičnu vlažnu nizinsku ekološku nišu, urediti močvarni okoliš i brojne vodotoke, kultivirati polja i šume te iskoristiti potencijale plodnoga agrarnog prostora za intenzivnu proizvodnju mediteranskih kultura. Upravo kronologija promjena okoliša u dugome povijesnom trajanju upućuje na prevladavajuću ulogu čovjeka u iniciranju okolišnih mijena. Tijekom srednjeg vijeka utjecaj čovjeka u prirodnom okolišu postupno slabi ili izostaje te dolazi do postupnog zapuštanja okoliša. Nizinska tla prepuštaju se prirodnim ciklusima te nestaju pojedina sela i zaseoci. Nakon više crkvenih redova koji su se izmjenjivali u upravljanju posjedom (benediktinci, templari i ivanovci) Venecija u posjed Vrane dolazi 1409. U doba feudalne uprave spomenutih crkvenih zajednica Vranom vodila se briga i o posjedima u susjednim selima. Templari su primjerice intervenirali u hidrološku osnovu Kakme i skretali potok Jablan na vlastiti mlin, eksploatirajući tako jezerski ornitološki i riblji fond. ${ }^{5}$ Zbog uloge Vrane kao raskrižja kopnenih prometnih ruta i položaja blizu pomorskih pravaca, bogatstvo i moć templara nasljeđuju ivanovci (hospitalci) te dodatno preuređuju vlastelinstvo i šire voćnjake, maslinike, njive i vinograde. Tijekom osmanske uprave počinje duže razdoblje ratne nesigurnosti, koja temeljito određuje ekonomske aktivnosti u pograničju. S druge strane, feud (mezra) lokalnih feudalnih magnata iz obitelji Memibegović usprkos depopulaciji obnavlja se doseljavanjem te se poljoprivreda

$4 \quad$ Stari je rimski vodovod iz 98. u Jader transportirao vodu od izvora Bibe pokraj Vrane. Drugim se krakom povezuje rijeka Krka (Titius) i Vransko jezero s Primorjem (Kos, 1971: 477-502).

5 Kao najbogatiji crkveni red u 13. stoljeću oni su bili izuzeti iz jurisdikcije mjesnih biskupa, pa su uz posjede u okolici dobili na upravu i tvrđavu Tinj te grad Ljubu (Kolanović, 1971: 217). 
održala, dok Vrana postaje najvažnija utvrda osmanske krajine (serhata) (Spaho, 1990: 431-436). U upravnom smislu smještena je prvotno unutar kliškoga, a nakon 1580. unutar krčkog sandžaka. Njezino podgrađe razvija se kao varoš sa sadržajima nužnim za potrebe vojnika i njihovih obitelji, dok okolica u gospodarskom smislu ostaje agrarnoga karaktera. U susjednom Tinju bilo je sjedište posjeda obitelji Sokolović, bosanskog beglerbega Ferhad-paše. ${ }^{6}$ Korisnici posjeda održavali su kanale, napunili vodom opkope, a 1644./1645. Jusuf Mašković, carigradski službenik podrijetlom iz Vrane, počeo je graditi karavan-saraj (Maškovića han). Obradive zemlje lokalnog stanovništva bile su u Tinju, Rogovu, Tukljači i Vrani, a i primorski su koloni kosili i zakupljivali ševar te lovili ribu za desetinu vranskom begu (Kos, 1971: 492). Zbog važne komunikacijske i geostrateške pozicije posjeda njegovi vlasnici s vremenom zapostavljaju ekonomsku važnost eksploatacije polja i jezera kao izvora blagostanja te prednost daju fortifikacijskoj ulozi same vranske utvrde. Veliki mletačko-osmanski ratovi tijekom 17. stoljeća, ${ }^{7}$ ali još više iscrpljujući i dugotrajni »mali rat«, odnosno prekogranični upadi neregularnih, često pljačkaških skupina na obje strane granice nakon njih, a potom i mletačka rekonkvista, završavaju ne samo devastacijom i destrukcijom fortifikacija, vojnih i civilnih objekata već i degradacijom prirodnog i kulturnog pejzaža. Izmijenjeni prirodni i kulturni krajolik ne omogućuje više dotadašnju ekonomsku eksploataciju jer su Mlečani i njihovi morlački saveznici prilikom osvajanja kotarskih utvrda, posebno tijekom Kandijskoga rata, spalili polja, dio naselja i mlinove. Stipan Sarić i Ilija Smiljanić zauzimaju pritom i Vranu. Usto se zapuštaju kanali i solane te ostali objekti koji su bili temelj dotadašnjeg prosperiteta posjeda. Štoviše, mletačke vlasti odgađaju njihovu obnovu, koristeći se njima kao prirodnom barijerom za eventualne ponovne osmanske upade.

\section{RAZVOJ VRANSKOG FEUDA POD MLETAČKOM UPRAVOM I INVESTITURA OBITELJI BORELLI}

Nakon mletačkog osvajanja posjeda 1684., dio lokalnih obitelji ostaje čekati nove gospodare. Na ekonomski i okolišno devastirani prostor te, još važnije, demografski gotovo opustjeli kraj Mlečani nastoje privući nove stanovnike i trajno ih stabilizirati te im stoga nude povlastice. Uz novodoseljeno pravoslavno stanovništvo vraća se i dio iseljenoga domaćeg te

Prema izvorima iz Znanstvene knjižnice u Zadru (dalje ZKZD), Manuscritti, br. 16530, Ms 459. S. Gliubavaz, Storica disertazione del contado e territorio di Zara, f. 105-106; Traljić, 1971.

7 Odnosi se na Kandijski (1645. - 1669.) i Morejski rat (1684. - 1699.). 
se u postojeći složeni etnički i konfesionalni konglomerat doseljavaju novi stanovnici katoličke vjeroispovijesti. Zbog ratnih je operacija posjed bio zapušten i pretvoren u močvarno leglo malarije, kanali i jaruge iz osmanskog vremena zarasli su, a gusti ševar nije dopuštao odvodnjavanje viška vode. Posjed je često mijenjao vlasnike, pa je država pokušala javnim radovima urediti kanale za odvodnjavanje i dobiti nova plodna tla i pitku vodu jer nakon 17. stoljeća i ratnih opasnosti primarnu važnost ponovno preuzimaju polje i jezero (HR-DAZD, SGP, Alvise Mocenigo, kut. 63, II: 297). Sredinom 18. stoljeća vranski feud zapremao je površinu od četrdeset tisuća padovanskih kampa, odnosno gotovo 15.000 hektara, od čega se samo jezero prostiralo na $30,16 \mathrm{~km}^{2}$ površine. Od ukupne površine svega je osmina bila pod oranicama, vinogradima, livadama, pašnjacima i šumama, a sve ostalo bilo je močvarno i neiskorišteno tlo. ${ }^{8} \mathrm{Na}$ obradu su ukupno podijeljena 6064 padovanskih kampa zemlje, od čega je samo dio bio pogodan za krčenje, dok je većina te zemlje bila trajno vlažna i neobradiva. ${ }^{9}$ Vrana je bila u statusu državnog dobra sve do 1752., kada su je Mlečani kao investituru ustupili obitelji Borelli. Feud je obuhvaćao devet naselja; Tinj, Banjevac, Vranu, Radošinovac, Turanj, Biograd na Moru, Sveti Filip i Jakov, Dobru Vodu, Stankovce i Pakoštane u zadarskom okružju te sa šibenskog područja Betinu i Murter s oko 2500 do 3000 stanovnika (Stanojević, 2004: 177). U to je vrijeme bio najveći i najznačajniji feud u Dalmaciji. Kako Borellijevi nikada nisu živjeli na posjedu, njihovi upravitelji organizirali su i nadgledali provođenje melioracijskih radova, obrađivanje zemlje, pobiranje podavanja od zakupaca zemlje ( $u$ iznosu od desetine do čak polovine uroda), ubiranje naknade na ime travarine te rješavanje otpora lokalnog stanovništva zbog uskraćivanja tih podavanja (HR-DAZD, SGP, Girolamo M. Balbi, kut. I: 224). Povoljni životni uvjeti, ali i povećane potrebe za radnom snagom potiču, ali i iziskuju dodatno naseljavanje. Svaki je novi stanovnik dobio dva kampa zemlje koju je valjalo obraditi te po kampu zasaditi osam stabala masline, murve, bajama ili kestena, dijelom zbog dodatne opskrbe hranom, ali i zbog sprečavanja erozije tla (HR-DAZD, Stampe, svežanj III, br. 94/1). Pritom su stanovnici triju sela (Vrana, Banjevac i Tinj) dobili na obradu većinu zapuštenog zemljišta na vlažnim prostorima. Zatečeni, a posebno novi kmetovi i težaci povlasticom su oslobođeni od feudalnih podavanja na čak dvadeset

$8 \quad$ Na planu vranskog dobra inženjera Giovannija Battiste Lodolija iz 1746. te potom 1756. zabilježen je točno 40.881 padovanski kamp i detaljne mogućnosti gospodarskog iskorištavanja (HR-DAZD-383. Kartografska zbirka, inv. br. 94/A, HR-DAZD Stampa fedel co: Andrea Borelli Assuntor di Giudizio etc...; 9-13).

9 Plan podjele obradivog dijela vranskih močvara (terreni arativi) stanovnicima okolnih sela, pa i Tinju, vidljiv je u nacrtima iz HR-DAZD, OBG, svežanj 2, C/ 3-12. 
godina, no zbog pravnog partikularizma, ali i nepoštovanja stečenih prava, njihov se status od slučaja do slučaja razlikovao (Stanojević, 2004: 178). Providur Contarini oslobodio je zatečene i nove obrađivače zemlje od tlake 1761., premda se povlastica neplaćanja desetine zadržala i dugo nakon završetka radova na melioraciji (HR-DAZD, SGP, Alvise Contarini, kut. I: 1-2; Stanojević, 2004: 178).

Iako su bili zainteresirani za povećanje eksploatacijskih osnova vranskoga feuda, Mlečani su na temelju iskustva na isušivanju močvara rijeke Po mogli pretpostaviti potencijalne rizike, dugotrajnu financijsku zahtjevnost i ekonomsku neizvjesnost melioracije kotarskih močvara. Stoga Senat prihvaća privatnu inicijativu i privatizira projekt melioracije Vrane koji su predložili Francesco Borelli i njegovi poslovni partneri. S vremenom su se ortaci (Vincenzo de Medici i Domenik Balio, braća Zavoreo iz Šibenika i Antun Feltri iz Venecije) smjenjivali i postupno istupali iz ugovora koji ih je obvezao na financiranje isušivanja močvara u roku od dvanaest godina, ponajprije probijanjem kanala Prosika od jezera do mora (HR-DAZD, SGP, Alvise Contarini, kut. II: 264, 265; SGP, Francesco Diedo, kut. I: 130, II: 151). Pa iako su po ugovoru na dvadeset godina bili dužni osloboditi zakupce zemlje (kolone i težake) dijela novčanih podavanja i tlake, s druge su strane sami preuzeli plaćanje desetine poreza državi. Borellijevi (Conte di Vrana) sami su bili obvezni platiti 3500 mletačkih lira na ime investiture kao zakupno-nasljednog prava, uz dodatnih 17.000 lira godišnje državnoj blagajni te dvije lire po isušenom kampu (Peričić, 1971:392). Kao obrazovani i moderni europski fiziokrati i intelektualci općenito, oni su uvođenjem reformi i javnih radova, okrupnjavanjem posjeda te kroz skrb o školstvu i zdravstvu, zalaganje za zdravstveno i trgovačko osamostaljenje od Venecije i otpor monopolu trgovine s Bosnom kroz favoriziranu splitsku skelu te stalnim ulaganjima nastojali osposobiti stanovnike potencijalno plodnoga kraja za samoodrživo gospodarenje i ujedno zadovoljiti vlastite kroz zadovoljavanje ekonomskih potreba stanovnika (Božić-Bužančić, 1995: 241-245; Čolak, 1957: 398). Troškovi neizvjesne okolišno-ekonomske avanture isušivanja i melioracije Vrane rasli su, pa su ubrzo nakon investiture zbog napuštanja partnera gotovo potpuno pali na teret obitelji Borelli. Osim toga su dio novca od prikupljenih podavanja Borellijevi ulagali u unapređivanje posjeda, što je relativne prihode od posjeda umanjilo $u$ odnosu na one partnerske obitelji Galbiani iz Šibenika (HR-DAZD, OBG, svežanj 60, sveščić I/IV: 1752. -1798). 


\section{PREDMODERNE MIGRACIJE - MEĐUIGRA RAZNIH POKRETAČA SELIDBI}

Upravo je interakcija čovjeka i njegova okoliša u dugome povijesnom trajanju rezultirala mobilnošću, dijelom planskom i organiziranom, ali ne nužno samo takvom već i onom više nedobrovoljnoga karaktera (de Vries i Goudsblom, 2003). U raznim je trenucima povijesti, na različitim područjima, osiromašivanje do tada ekonomski prosperitetnog okoliša, prije svega kroz nestašicu zemljišnih resursa i iscrpljivanje obradivog tla, uvjetovalo nastanak sukoba i raznih oblika ekoloških migracija (Mesić, 2002). U slučaju neodrživih i negostoljubivih životnih uvjeta ili ekonomske neravnoteže na jednoj lokaciji, privremena ili trajna migracija postala bi jednom od strategija opstanka za pojedince, obitelji ili čitave zajednice. Bez obzira na dobrovoljnost ili prisilu koja je ljude poticala ili pak tjerala na seljenje upravo je osiromašivanje nekada prosperitetnog okoliša moglo pokrenuti »okolišno inducirane migracije«. S druge strane, prosvjetiteljski ideal o svrhovitosti povijesnog razvoja u obliku priželjkivanoga i proklamiranoga civilizacijskog napretka utirao je put projektima kultiviranja i »podčinjavanja« prirodnog okoliša ljudskome. Ideje o ekonomskim razvojnim projektima imperijalnih vladara nužno su zadirale i u sociodemografske procese.

Od vladara i države poticane, planske i organizirane kolonizacije u doba prosvjetiteljstva dovodile su do prostornog premještanja i raseljavanja stanovništva $\mathrm{u}$ obliku iznuđenih i prisilnih migracija, što je poslije također odlika nekih kolonizacijskih procesa u razdoblju socijalizma (Bara i Lajić, 2009). Takve su migracije bile vođene ponajprije ekonomskim i demografskim opravdanjima, iako su i okolišni faktori igrali ulogu, jer se preseljavanje uglavnom odvijalo iz okolišno "siromašnijih" i pasivnijih (brdskih i krških) područja u okolišno »plodnija « i prosperitetnija (nizinska) područja, u ovom slučaju u specifični mikrolokalitet Ravnih kotara. Relativno povoljna mikroklima, potencijal zadobivanja plodne zemlje isušivanjem i gradnjom irigacijskog sustava, svojevrsne statusne i financijske povlastice te zanimljiv geografski i politički položaj višegraničja (mletačkoga, osmanskog, ali i nedalekoga habsburškoga graničnog prostora) mogli su biti i privlačni faktor za neke individualne useljenike koji su svoje životne šanse htjeli okušati u tom području.

Tako su i protomoderne migracije ranoga novog vijeka na vranskom feudu potaknute time što se demografski manjak nastojao korigirati privlačenjem i planskim doseljavanjem stanovništva. Najmasovniji dolazak Morlaka iz brdskoga pograničnoga bukovičkoga kraja nije se temeljio toli- 
ko na tamošnjem višku stanovništva koliko na potrazi za većim zemljišnim posjedom nužnim za kretanje, nalaženje ispaše i osiguravanje egzistencije ekstenzivnih stočara. Stočarstvo je stoga kao temeljna gospodarska djelatnost uzrokovalo gospodarsku prenaseljenost, odnosno krajnje iscrpljivalo kapacitet nosivosti prostora, a gustoća naseljenosti od $12 \mathrm{st} . / \mathrm{km}^{2} \mathrm{u}$ Kotarima premašivala je mogućnosti stočarske ekonomije na krškoj podlozi (Pisani, 1893: 1, 96-98; Baras, 1977: 81-82, 237). Nomadizam je u ovom slučaju bio pragmatična alternativa rudimentarnoj zemljoradnji, posebno u uvjetima ratne devastacije aridnoga mediteranskoga krša, jer je stoka lako pokretljiva. I morlačka su transhumantna kretanja bila dio široke lepeze migracijskih obrazaca koji su prethodili suvremenim migracijama. $S$ druge je strane morlačko preseljavanje u Kotare bio specifičan tip kolonizacije toga vremena, s tek posrednom dimenzijom okolišnih migracija jer iako su sudjelovali u melioraciji terena, oni to inicijalno kao useljenici nisu znali. Oni su, uz obrambene zadatke koje su imali, radili i na projektu isušivanja, mijenjajući posjedu ekološku, tj. okolišnu, ali i ekonomsku, a posebno javnozdravstvenu vrijednost. Kroz unos novih elemenata materijalne i duhovne kulture migracije Morlaka postaju tako »povratni proces u kojemu je čovjek u seobi mijenjao svoja podneblja, a nova podneblja mijenjala su njega « (Heršak, 2005: 78), jer migracije vrlo često jesu određena konstanta unutar društveno-ekonomskih povijesnih mijena. Mletačka Dalmacija profitirala je od različitih oblika doseljavanja, pa u manjoj mjeri i ekskluzivnim privremenim migracijama plemstva, odnosno činjenicom da je vlasništvo vranskog posjeda došlo u ruke obitelji Borelli. Upravo su obrazovani i financijski neovisni članovi tih obitelji omogućili prijenos dijela zapadnojadranskih iskustava i znanstvenih spoznaja, poput fiziokratskih ideja na istočne obale Jadrana.

\section{TIPOLOGIJA DOSELJAVANJA: TIPOVI, OBLICI, OBRASCI I INTENZITET MIGRACIJA NA VRANSKOM FEUDU}

Kako je jedan od stupova gospodarskog razvoja vranskoga kraja, a ujedno i preduvjet za pokretanje isušivanja većih razmjera bilo stanovništvo, kojeg nije bilo dovoljno, kratkoročno je bilo nužno osigurati njegovo brzo povećanje kroz doseljavanje. Nekoliko je prevladavajućih tipova migracija zabilježeno na sjevernodalmatinskom posjedu, a svaki od njih na različit je način pridonosio razvoju prostora, što zorno ilustrira rekonstrukcija prostornoga kretanja stanovništva na slici $1 .{ }^{10}$

Izvor: Isječak karte zapadnog dijela Mletačke Dalmacije P. Santinija iz 1780. (Nouvelle carte de la partie occidentale de Dalmatie), NSK, Zbirka starih karata i atlasa, SJ-Z-XVIII-18. 
Slika 1. Migracijska mreža za naselje Tinj

Figure 1. Migration network for the Tinj village

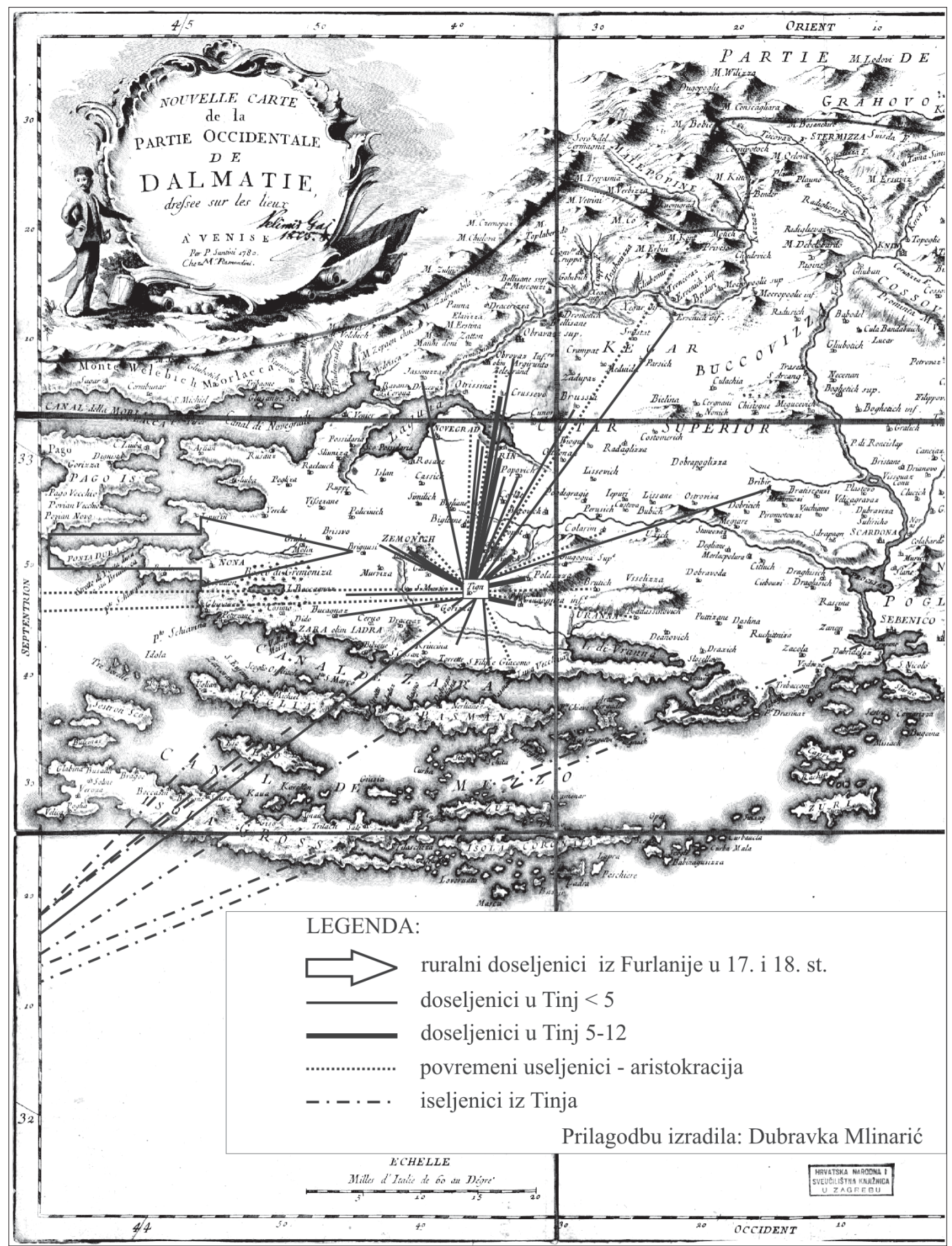


Najrjeđi oblik useljavanja isprva su bile periodične pravno-poslovne i prekogranične (odnosi se na granice Mletačke Dalmacije) migracije talijanske aristokracije kao vranskih posjednika, primjerice članova obitelji Borelli iz Bologne. Prvi zabilježeni član obitelji jest zapovjednik kninske tvrđave 1738., Bartul, čiji se sin Frane (Francesco) posebno posvetio vranskom feudu. Oni se na prostor sjeverne Dalmacije naseljavaju privremeno i pritom ne žive na posjedu, nego u većim gradovima na obali. Borave u Zadru, Šibeniku, Svetom Filipu i Jakovu ili Betini (Čolak, 1957: 398-401). Usprkos nestalnosti boravka u Dalmaciji, oni su posjedovnim i političkim vezama, financijski, ali i inovacijama bitno pridonijeli razvoju Ravnih kotara. Za pokretanje i održavanje mehanizma toga tipa migracija bila je manje bitna ekološka situacija na Vrani od političkih odnosa Venecije i Dalmacije i pravnog mehanizma investiture kojim su posjede i mogućnost njihove eksploatacije mogli nasljeđivati članovi feudalnih obitelji. Druga vrsta prekograničnih, ali ovog puta migracija trajnijega karaktera bilo je doseljavanje podanika, tj. talijanske radne snage iz sjevernotalijanske pokrajine Furlanije, posebno s područja oko rijeke Tagliamento i donjeg toka rijeke Soče. Još se sredinom 20. stoljeća dio vranske okolice nazivao Furlanijom, ${ }^{11}$ prema doseljenicima iz sjeverne Italije (Kulušić, 1959: 100). Oni se doseljavaju tijekom 18. stoljeća na napuštena selišta izumrlih ili odseljenih obitelji u sjeverozapadnom dijelu posjeda.

Kao treću i najbrojniju skupinu useljenika država na veći dio napuštenih selišta kolonizira morlačko stanovništvo iz Bukovice, privučeno obećanim poreznim povlasticama i vođeno svojim harambašama i serdarima. Morlacima Donjega kotara Zadarskoga okružja zapovijedali su serdari iz obitelji Smiljanić u Zemuniku, a biogradski guvernadur Bortolazzi (Bortulačić) nametnuo se jačanjem utjecaja i kao nadintendant Vrane (Mayhew, 2008: 165-173). Morlaci su dovođeni s prekograničnih osmanskih posjeda, iz Hercegovačkog i Kliškog sandžaka, odnosno preko ondašnjih državnih granica (linea Nani 1671. i linea Grimani 1699.), sa sjevernih obala Zrmanje. Dio ih je došao još tijekom osmansko-mletačkih ratova, što je vidljivo iz rijetkih osmanskih popisa posjeda (deftera) za pretežito vojničko stanovništvo, doseljeno iz Dalmatinske zagore, Cetinske krajine i Hercegovine. U manjoj mjeri dolazi i do povratka srednjovjekovnoga hrvatskog stanovništva koje je izbjeglo pred Osmanlijama, o čemu osim kontinuiteta toponima svjedoče i izvori (Mayhew, 2008: 167; Rimac i Mladineo, 2009: 16). Doseljenici popunjavaju demografske praznine nakon mletačkog zaposjedanja Nove i Najnovije stečevine.

11 Kartografski izvori biogradskog primorja bilježe horonim odnosno hidronim Furlania (HR-DAZD, OBG, svežanj 96, katastarske mape, Zarra Vechia). 
Iako migracije imaju dimenziju radno-okolišnih samo utoliko što će Morlacima melioracija terena naknadno, uz obranu, postati redovita obveza, oni nisu inicijalno zbog toga useljavani, već se ratna nesigurnost i obrambene potrebe maskiraju privlačnim povlasticama i priznavanjem njihove samouprave te se iskorištavaju kao akcelerator morlačkog angažmana u pograničju. Temeljno načelo dodjele dvaju kampova po članu obitelji nije se uvijek poštovalo, a ni mletačka agrarna politika nije slijedila logiku demografskog rasta morlačkih obitelji. Zbog pravne nestabilnosti u uređenju posjedovnih odnosa i razlike $u$ pravnom statusu pri naseljavanju između starih primoraca i novih doseljenika, sukobi su bili neizbježni (Rimac i Mladineo, 2009: 20). Tijekom 18. stoljeća stočarsko se stanovništvo dalje raseljava u disperzne patronimičke rodovske zaseoke i sela (Raštević, Biljane Donje, Lišane Tinjske i Tinj), a jaka struja doseljavanja iz Bukovice, posebno iz okolice Medviđe, vidljiva je i u raširenosti istih prezimena (Dlaka, Uzelac, Tepšić, Matković, Milković, Knežević, Bašić, Jokić i Macura) (HR-DAZD, OBG, svežanj 98; br. 72 Albero Genealogico di Tign; Rimac i Mladineo 2009: 78). Spomenuta sela redom su patila od hiperendemske malarije, što je poslije umanjivalo njihovu demografsku i ekonomsku snagu (Mlinarić, 2006b: 42).

Kao protomoderni tip migracija ta su kretanja bila vezana uz neracionalno iskorištavanje zemlje, jer su doseljeni stočari iskazivali otpor prema sesilizaciji i obradi plodne isušene zemlje te uzgoju ratarskih kultura, posebno u ratnom okružju. Stoga su osim demografske redistribucije takva planska preseljenja predstavljala kulturnu difuziju te pridonosila transferu drukčijih vještina. Heterogena je skupina zdravih brdskih useljenika s pobrđa Kotara i visoke Bukovice predviđena za realizaciju obrambenih, ekonomskih, melioracijskih i fiskalnih obveza na imanju, a očekivalo se i da će "gorštaci« biti otporniji na nepoznate groznične bolesti (Peričić, 1971: 405). Osamdesetih godina 18. stoljeća doseljeno je oko tristo ljudi, što je još uvijek bilo nedovoljno jer je intenzitet uvjetovao prostorno-proizvodni kapacitet imanja.

Kao četvrti, najheterogeniji tip migracija prisutno je kontinuirano i neplansko lokalno seljenje, bilo trajno ili polutrajno. Uključivalo je lokalna sela na posjedu, ali i dalje destinacije unutar granica Mletačke Dalmacije, čak i iz priobalja ili otoka. Selilo se iz raznih razloga; zbog dolaska na melioracijske radove, naseljavanja ispražnjenih kuća zbog izumiranja neke obitelji, dijelom i zbog endemičnih malaričnih groznica, ženidbenih veza (uključujući i domazetstvo) ili čak pendularno, u obliku transhumantnih stočarskih kretanja, koja su se zadržala i do 20. stoljeća. Ipak, ukupni broj doseljenika na posjed ostao je nepoznat, stoga što se u izvorima s feuda (OBG, Alberi Genealogici) nalaze pojedinačni podaci o investiranim glavama obitelji, tek rijet- 
ko s naznakom odakle potječu. Istodobno su osmanski ratovi i devastacija, glad i siromaštvo potaknuli obrnuti migracijski proces, odnosno iseljavanja s posjeda. Odvijali su se u više smjerova, u ovisnosti o prilici i mogućnostima migranata: dijelom prema susjednim selima, udaljenijim selima, većim gradovima, u Istru, pa čak i prema osmanskom zaleđu, ali i prema Šibenskom kotaru i otocima. ${ }^{12}$

\section{DEMOGRAFSKE SLIKE VRANSKOG POSJEDA}

Kako za temeljitiju demografsku analizu ranonovovjekovnih kretanja nedostaju akronijski usporedivi brojčani podaci, nužda je nametnula upotrebu podataka o naseljenosti. ${ }^{13}$ Nakon već spomenutog razdoblja velike i kontinuirane naseljenosti tijekom antike i stagnacije u srednjem vijeku, stanovništvo šireg prostora općenito bilježi spor brojčani rast tijekom ranoga novoga vijeka, koji ograničava, između ostaloga, i zapušteno gospodarstvo. Uz vlaško ${ }^{14}$ defteri bilježe i kolonizaciju muslimanskoga vojnog stanovništva (Hafizović, 2016). Sve navedeno omogućilo je diskontinuiranu, ali relativno gustu naseljenost, temeljenu na poljoprivrednoj i komercijalnoj snazi prostora, dobroj povezanosti te gospodarskom nadopunjavanju priobalja i zaleđa, ali i na ugodnom životu zbog plodnog tla i pitke vode. Protuosmaski ratovi uzrokovali su demografsku destrukciju i pojačano iseljavanje. Stoga su Borellijevi u trenutku ulaska u posjed dobili relativno veliku površinu, ali s malim brojem stanovnika. ${ }^{15}$ Upravo radi zadržavanja staroga i novodoseljenog, ali i privlačenja novoga stanovništva, na feudu vlasnici počinju skupe projekte melioracije, kao suprotnost intenciji iseljavanja iz močvarnoga, bolestima zahvaćenog i nezdravog te često pljačkanoga kraja. Premda usporedni popisi stanovnika posjeda između 1752. i 1755. bilježe blagi porast stanovništva (na 3104, što je povećanje za 178 stanovnika) te

12 Premda se gustoća stanovništva otokâ povećala, a s njome i potreba za pašnjacima, pa su ih bili primorani zakupljivati na Kornatima, novija istraživanja dovode u pitanje teorije o značajnijem doseljavanju morlačkih izbjeglica i stočarskih prebjega iz zaleđa na otok Murter u 16. i 17. stoljeću (Juran, 2005: 139-149).

13 I dok je od antičkih vremena kao naselje zabilježena samo Vrana, srednjovjekovlje je ostavilo arheološke tragove u Vrani, ali i manjim zaseocima, poput Gorice, Lišana, Tinaja, Vrbice, Rogova i Sikova (Jurić, 1990: 281).

14 Mletački katastar iz 1709. zabilježio je gotovo 30\% stanovnika Tinja kao muškarce sposobne za vojsku, što posredno govori u prilog njihovu morlačkom podrijetlu (Rimac i Mladineo, 2009: 69).

15 Kao što je vidljivo iz Grimanijeva popisa obitelji, stanovnika i zemljišnih posjeda iz 1755. (HR-DAZD, OBG, svežanj 98/27), krajem stoljeća, prema popisu iz 1790., sela vranskog feuda brojila su 387 obitelji i 561 čovjeka sposobnog za oružje (HR-DAZD, OBG, svežanj $1 / 7)$. 
nešto veći iskrčenoga obradivoga tla (na 9551, što je povećanje za 216 kampa), tek se u manjem broju kuća povećao broj članova obitelji. ${ }^{16}$ No jedan podatak upućuje na nestabilnost naseljavanja i trajno mijenjanje korisnika zemlje koji su nastanjivali ispražnjena selišta. ${ }^{17} \mathrm{Na}$ prostoru devet sela posjeda nestalo je izumiranjem posljednjeg člana i povratom njihove zemlje državi mnogo obitelji.

Za paradigmatsko naselje ovog istraživanja, močvarni i malariji podložan Tinj, zabilježeno je da izumire 28 ili $51,8 \%$ obitelji, što je gotovo dvostruko više od ostalih sela posjeda, izuzev Turnja, jer u Vrani izumire jedna obitelj ili 3,6\%, u Biogradu na Moru 33 obitelji ili 28,4\% te u Pakoštanama tri obitelji ili 18,8\%. ${ }^{18}$ Ravnoteža prirodnoga demografskoga kretanja u priobalnim selima, podložnijima maritimnom utjecaju, za razliku od nešto nestabilnijih trendova u naseljima u unutrašnjosti, još je uvijek odgovarala oscilacijskoj kvaliteti predtranzicijske demografske povijesne stvarnosti.

No uz spomenute prostorne i vremenske nepravilnosti u distribuciji, naseljenost se i prostorno pomicala, tako da je kontinuitet naselja bilo teško pratiti. Vidljivo je da su najnepovoljniji životni uvjeti u dijelu naselja oko močvara djelovali ograničavajuće na veličinu obitelji, a nezdravi je močvarni prostor, za razliku od zdravijeg priobalja, povećavao smrtnost posebno ugroženih društvenih skupina. Mortalitet djece mlađe od dvije godine bio je visok, pa u Tinju troje ili više djece umire u čak petini tamošnjih kućanstava. Stalna egzistencijalna (ratna) ugroza, uz loše opće uvjete života na zapuštenom gospodarstvu i nizak standard, pomogla je zadržati kolebljiv i spor demografski rast na predindustrijskoj i predtranzicijskoj razini. S obzirom na vrijeme i prostor iz kojega se uselilo, stanovništvo zadarskog zaleđa bitno su odredile konfesionalne, ali i strukturne gospodarsko-proizvodne različitosti. Stoga je demografska, ali i zdravstvena nužda potaknula Francesca Borellija da svojim znanjima i melioracijskim inovacijama podigne standard, zadrži postojeće stanovništvo i nastoji ekonomski stabilizirati posjed.

16 Isti Grimanijev popis kao i u bilješci 17.

17 Mletački katastar iz 1709. zabilježio je da je samo 64\% zemljišta u Tinju pripadalo seljanima Tinja (Rimac i Mladineo, 2009: 68-69). Ostalo zemljište je tijekom 18. stoljeća bilo u posjedu stanovnika susjednih naselja, onih koji su odselili ili su obitelji zabilježenih korisnika u međuvremenu izumrle. Na ispražnjena su područja, sukladno kasnijim statistikama, naseljeni novi stanovnici, među kojima i Bukovčani (HR-DAZD, OBG, svežanj 98; br. 72).

18 Izvori su genealoška stabla pojedinih sela feuda Borelli u kojima je popisano stanovništvo (HR-DAZD, OBG, svežanj 98, Albero Genealogico /AG/ di Tign, br.72, AG di Wrana, br. 74, AG di Pacostiane br. 71, AG di Zarravechia, br. 75). 


\section{MELIORACIJSKI RADOVI,ASANACIJA VODA I DRENAŽA (ODVODNJAVANJE) VLAŽNIH TERENA}

Borelli je odgovor pronašao u uređivanju vodotokâ na posjedu, u asanaciji terena i drenaži tla, kao u prvim većim melioracijskim zahvatima nakon zaboravljene antičke prakse. Projekt je obuhvatio raznolik prostor, a zasnivao se na uređivanju bogatoga hidrogeografskog sustava vodotoka i kanaliziranju obilja vode na ukupnoj površini sliva od $30 \mathrm{~km}^{2}$, na prostoru izvora, 2155 ha polja, 580 ha močvara i blata, te niveliranja 3000 ha Vranskog jezera (Prtenjača, 1990: 683). Zemuničkim poljem tekla je Jaruga, prolazeći uz sela Goricu, Raštane, Sikovo i Podjarugu. Kotarka je protjecala Vranskim poljem i blatom, također relativno blizu prvih naselja. Prije su regulacije svojim poplavljivanjem počesto onemogućivale poljoprivredne djelatnosti stanovništvu tih sela. $U$ to vrijeme stanovnici sela uz močvaru močvari su oteli nove velike količine obradive zemlje. Uz Vranu, koja dobiva 47 kampa i Banjevac s 84 kampa, Tinj je sa 66 kampa bio potpuno okružen i ispresijecan vodama čak triju lokava, više zdenaca, močvara i blata. ${ }^{19}$ Time se potpuno novi prostori privode poljoprivrednoj eksploataciji, što pokazuje i usporedba katastika Vendramin i Grimani, nastalih u rasponu od pola stoljeća početkom 18. stoljeća.

Na istočnom rubu Vranskog jezera Borellijevi su prvi proveli veliki melioracijski zahvat prokopom kamenoga hrpta Tatinje (Prosika) i uređenjem okolnoga blata, većinom sezonskim radom, ali i radom težaka, bilo iz Bukovice ili s otokâ i iz Primorja. Za provođenje isušivanja valjalo je svakako nadomjestiti veliki ratni demografski deficit, posebno vezan uz Kandijski rat. Saniranje močvara i doseljavanje postupno potiču demografski rast te porast životnog standarda, pa preseljenje koristi i državnoj blagajni i feudalnom gospodaru. $\mathrm{S}$ druge su se strane malarične groznice upravo i »zadržavale « u »svježemu «, odnosno novodovedenom zdravom stanovništvu. Čiste se i popravljaju seoski bunari i izvori na poljima i provodi se niz manjih sanacija problematičnih vodenih objekata (Nežić, 1939; Hekman, 1971; Peričić, 1971).

Godine 1770. prokopan je kanal Prosika na istočnom rubu jezera, u širini od četiri i duljini od $850 \mathrm{~m}$, zbog čega je razina vode pala. ${ }^{20}$ Izgradnjom odvodnih kanala tereni jesu dijelom isušeni i meliorirani, ali taj zahvat nisu

19 Kartografski izvori svjedoče o izrazito velikom bogatstvu hidroloških objekata Vrane i Banjevca, koji su presijecali posjede pojedinih uživatelja, kao što je vidljivo u nacrtima feuda (HR-DAZD, OBG, svežanj 2/C, svežanj 3 H/5 ili svežanj 4).

20 Karte horizontalnog i vertikalnog presjeka kanala Prosika nalaze se u HR-DAZD, OBG, svežanj $4 \mathrm{M} / 5$; svežanj $6 \mathrm{M} / 5$. 
pratili usporedna šira asanacija tla i čišćenje odvodnih kanalića. ${ }^{21}$ Oni više nisu služili navodnjavanju, nego su bili izvor anofelizma, pa se malarična endemija zadržala u okolišu jer se »tresavice « po simptomima nalik na malariju nije poznavalo, kao ni njihovo liječenje ili prevenciju. Stoga je bolest inicijalno odredila i demografski ugrozila prostor u većoj mjeri od ekonomskog prosperiteta koji je donijela sama melioracija. Zbog napuštanja kuća u Tinju i okolici čak se donekle poništavaju i kolonizacijski napori naseljavanja Morlaka. Iako su sami preuzeli dobar dio financijskog tereta za isušivanje i Morlake privukli poreznim povlasticama, Borellijevi su primorali stanovnike primorskih sela feuda (Pakoštane, Sveti Filip i Jakov, Biograd na Moru i Turanj) ili težake kojima bi isteklo razdoblje povlastica da godišnje na kopanju Prosike odrade dvadeset dnevnica po glavi stanovnika (HRDAZD, Stampa fedel... 199-201, 222). No srednjoročno i dugoročno gledano, melioracija, čišćenje i popravljanje zdenaca te čišćenje jaruga na poljima i izvora postupno ograničavaju razvojni ciklus ličinke malaričnoga komarca te se time reduciraju malarične bolesti u okolici. U prvoj polovini stoljeća prostor obrađenih zemalja povećao se gotovo za trećinu, kao što je vidljivo u pregledu iz katastika Vendramin iz 1709. i Grimanijeva katastika iz 1756. (tablica 1), pri čemu je samo za obradiva tla Tinja taj broj gotovo četverostruko narastao. Tijekom idućih desetljeća u određenim ciklusima stanovnici su nastavili otimati zemlju močvarama i blatu, što otkriva usporedba pojedinačnih karata, ali i sustavnih katastarskih pregleda većeg područja u široj vremenskoj perspektivi. ${ }^{22}$

Tablica 1. Pregled novih zemalja na feudu privedenih obradi polovinom 18. stoljeća

Table 1. Overview of the new cultivated land on the feud in the middle of the $18^{\text {th }}$ century

\begin{tabular}{lcc}
\hline Selo & $\begin{array}{c}\text { Katastik Vendramin } \\
\mathbf{( 1 7 0 9 )}\end{array}$ & $\begin{array}{c}\text { Katastik Grimani } \\
\mathbf{( 1 7 5 6 )}\end{array}$ \\
\hline Vrana & $\begin{array}{c}1026 \text { kampa obradive } \\
\text { zemlje }\end{array}$ & $\begin{array}{c}1506 \text { kampa obradive } \\
\text { zemlje }\end{array}$ \\
\hline Radošinovci i Dobra Voda & 1188 & 1205 \\
\hline Stankovci & 622 & 725 \\
\hline
\end{tabular}

21 Nacrti vranskih močvara (Pallude di Vrana) i plana isušivanja u: HR-DAZD, OBG Nacrti feuda, svežanj 2, C/2 do C/12.

22 Za prethodna razdoblja vidjeti u: HR-DAZD-382 Mletački katastri Dalmacije 17. i 18. stoljeća, kutija 68. 


\begin{tabular}{|c|c|c|}
\hline Selo & $\begin{array}{l}\text { Katastik Vendramin } \\
\text { (1709) }\end{array}$ & $\begin{array}{c}\text { Katastik Grimani } \\
\text { (1756) }\end{array}$ \\
\hline Pakoštane & 218 & 288 \\
\hline Biograd na Moru & 1835 & 696 \\
\hline Sveti Filip i Jakov i Turanj & 1116 & 1598 \\
\hline Tinj & $523^{*}$ & 2055 \\
\hline UKUPNO & $\begin{array}{c}6829 \text { (od ukupno } 39.919 \\
\text { kampa) }\end{array}$ & $\begin{array}{l}8075 \text { (od ukupno } 53.324 \\
\text { kampa, ostalo maslinici) }\end{array}$ \\
\hline
\end{tabular}

* Napomena: Stanovnici Tinja bez Bubnjana, prema tabličnom popisu redakcije popisa iz 1709., u svom su posjedu držali točno 526 kampa, jedan kvarat i 130 tavola zemlje. Pritom je čak 85\% ukupne površine koja je pripadala Tinju bilo upisano kao šuma i neobradive površine (Rimac i Mladineo, 2009: 69, 72).

Izvor: Znanstvena knjižnica Zadar (ZKZD), Feudi in Dalmazia sotto il governo veneto, Ms. 110: 88 .

\section{VRANSKI FEUD U RASKORAKU OKOLIŠNIH I EKONOMSKIH INTERESA}

Demografski prosperitet i stabilizaciju naselja Ravnih kotara od antike su gospodarski omogućivali intenzivna zemljoradnja, stočarstvo te eksploatacija šuma, močvara i jezera. Mletačko-osmanski ratovi, pljačkaški upadi i ostale posljedice sukoba na višestrukome krajiškom prostoru, praćeni ekonomskom i socijalnom neizvjesnošću i degradacijom na svim razinama, ali i demografskom stagnacijom i padom te migracijskim turbulencijama, odrazili su se i na labilni ravnokotarski nizinski ekosustav vranskoga feudalnog posjeda u 17. i 18. stoljeću. Nakon protuosmanskih ratova unutrašnjost je ostala dominantno orijentirana na stočarstvo, ali se i zemlja postupno kultivirala, unatoč prvotnoj zapuštenosti starih kanala. Bogata jesenska i zimska ispaša omogućivala je transhumantno stočarenje, koje je ovdje uključivalo i stada osmanskih podanika iz Bukovice, pa i Like. Obrtnička proizvodnja zadovoljavala je tek vlastite potrebe, a broj sitnih trgovaca bio je nizak. Lučki promet lokalnih prijevoznika gajetama, primjerice u Biogradu na Moru, bio je gotovo neznatan (Obad, 1990: 465-476).

Etničkim i demografskim promjenama uzrokovanim doseljavanjem narušavaju se i odnosi između socijalnih grupa. Iako je doseljenike privukao pravno izjednačeni status s domaćim stanovništvom, odnosno socijalne ili porezne povlastice, dočekala ih je i kvalitetnija te plodnija zemlja od one na 
kojoj su prije živjeli. Osim toga u ranome novom vijeku ekonomski i okolišni mehanizmi, ali i procesi u pograničju bili su izrazito međuovisni te ovisni o prirodnim ciklusima. Jednostavne gospodarske grane poput stočarenja činile su temelj kojem se zbog nižih ulaganja i manje zahtjevnog angažmana davala prednost, a močvarni ekosustav omogućivao je tek dodatno iskorištavanje. Iako se još za vrijeme osmanske uprave Halilage imanje održavalo zahvaljujući proširivanju vodenih opkopa, Mlečani su postupno davali primat obrambenoj funkciji naselja, dok su jezero i polja sve više zapostavljali. Razlog dijelom leži i u činjenici da su nestalni morlački stanovnici davali prednost stočarstvu. Osim toga se i agrarna proizvodnja nakon prvotnoga stezanja uskih gradskih teritorija u 15. i 16. stoljeću, i ponovnog širenja u 17. stoljeću, znatno promijenila.

Nazadovanje poljodjelstva kao ekonomskog temelja rezultat je pojave višestoljetnoga »malog ledenog doba« s ekstremno niskim ljetnim temperaturnim intervalima i propalim urodom, ali i političkog razdvajanja priobalja od zaleđa (Mlinarić, 2004: 51-52; Mlinarić, 2006b: 44-52). Odnosilo se to na političko razgraničenje s Osmanlijama, ali i na različite pravno-fiskalne sustave podaništva unutar Mletačke Dalmacije, razdvojene granicama Stare, Nove i Najnovije stečevine. Stoga se lokalno stanovništvo odlučilo za transhumantno stočarenje kao najpragmatičniju gospodarsku granu u slučaju ponovnih osmanskih upada, u kojima bi nepokretna imovina, ali i zemlja bile opustošene, dok se stoka mogla skloniti. Usprkos razgraničenjima mnogi Kotarani i Bukovičani, ali i Ličani preko granice, svoju sitnu i krupnu stoku napasaju na posjedu, plaćajući travarinu recipročno broju glava i vrsti stoke. ${ }^{23}$ Takva podvojenost praksi različitih oblika eksploatacije povijesnog okoliša, odnosno suprotstavljanja stočarstva zemljoradnji, bila je imanentna neracionalnom iskorištavanju zemlje ranonovovjekovnih pograničnih zajednica. Osim pašnjaka i livada najviše je bilo vinograda, voćnjaka i maslinika. Ratarstvo se polovinom stoljeća temeljilo na pšenici, ječmu, kukuruzu, prosu, tikvama, lubenicama i grahu. Iz količine propisanih podavanja vidljiva je kvaliteta tla koje se davalo na obradu. No kako je agrotehnička lepeza načina obrade tla uključivala arhaične metode i sredstva, stočarstvo se održalo kao temelj obiteljskoga gospodarstva, dok su lov ptica i ribolov na jezeru bili tek sporedni izvor prihoda. Stoga je prevladao interes da se plitka blata pretvore u plodno tlo, jer je zemlja bila potrebna za privlačenje novih doseljenika. Zapuštene močvare dodatno su omogućivale razvoj jata udomaćenih anofeličnih komaraca, koji su pak bili uzrokom jakih malaričnih groznica, dugotrajno endemično ukorijenjenih u nizinskom kraju.

23 Popis iznosa zaduženja za travarinu u HR-DAZD, OBG, svežanj 61/2. 
Iako se tom složenom tematikom ovdje nećemo više baviti, bolesti uzrokovane »lošim zrakom« vranskih močvara silno su slabile demografski i ekonomski potencijal posjeda i usporavale eventualni razvoj u svakom smislu. Prokop kanala Tatinje bila je stoga ključna točka ekološkog otiska velikoga melioracijskog projekta na Kotare i ujedno nagrada za napore Francesa Borellija u traženju ravnoteže između sredstava uloženih u melioracijski projekt i ostvarivanja okolišne, zdravstvene i gospodarske dobrobiti za lokalno stanovništvo. To ogromno hidrotehničko ostvarenje, bez presedana u prošlosti dalmatinske poljoprivrede, postavilo je temelje za proizvodnju hrane za potrebe cijele sjeverne Dalmacije. No problem je nastao u krivoj procjeni veleposjednika da će održivu ekološku ravnotežu močvarnog ekosustava u netipičnome plodnom kršu održavati novi useljenici - morlački stočari iz Bukovice. Oni nisu mogli zadovoljiti postavljeni cilj povećanja ekonomske produktivnosti radne snage, pa čak ni jačanja demografske osnove, dijelom i zato što su prije svega dovedeni kao krajišnici radi jačanja obrambene snage posjeda na Novoj stečevini (Acquisto nouvo), ali i ustaljenih stočarskih navika kretanja. Stoga je takvo stočarsko ekstenzivno iskorištavanje plodne zemlje, koju su prethodno mukotrpno iskrčili, bilo slabo produktivno te slijedom toga ekonomski neracionalno.

\section{ZAKLJUČAK}

Dobivanjem vranskoga posjeda u investituru 1752. obitelj Borelli provodi melioraciju močvarnoga tla i nastoji adekvatno valorizirati isušeni prostor nekadašnje antičke žitnice te u njega privući novo stanovništvo različitim povlasticama. Nakon isušivanja okolnih blâta odnosno prokopa kanala između Vranskog jezera i mora (Prosika), gdje se zapošljavaju Bukovčani, Primorci, pa i otočani, vlasnici su nastojali i dalje doseljavati »svježe« brdsko morlačko stanovništvo. Očekivali su da će ono biti izdržljivije i otpornije na nizinske malarične groznice koje su umanjivale produktivnost radne snage močvarnih prostora.

Niz pitanja postavljenih u ovom radu iziskivao je interdisciplinarnu analizu raznorodnih izvora, promatranih iz aspekta povijesti okoliša, ekohistorije, ekonomije i kartografije. Korelacija ranonovovjekovnih okolišnih i ekonomskih mehanizama i procesa u vranskome močvarnom okolišu upućuje na njihovu isprepletenost i određenost kontekstom smještaja na višestrukome krajiškom prostoru, kao prostoru brojnih kontakata različitih država, ekonomskih sustava i kultura. Možemo se upitati je li se provedeni privatni 
pothvat melioracije vranskih močvara pokazao ekonomski uspješnim projektom ili pak avanturističkim eksperimentom.

Iako je u osnovi bio hidrotehnički i ekonomski iskorak u duhu napora europskih intelektualnih elita 18. stoljeća (fiziokrata), vranski pothvat Francesca Borellija bio je i neizvjesni okolišno-ekonomski pothvat. I dok je na prepreke poput kontinuirane političko-vojne nesigurnosti u osmanskomletačkom pograničju, krajiških povlastica doseljenih Morlaka te otpusta od radnih podavanja, uključujući i rad na kanalima, Francesco Borelli još i mogao računati u trenutku predlaganja uvjetâ investiture, veći su problem realizaciji njegove vizije bili nerazumijevanje i izostanak političke podrške Venecije te neuspjeh u zadržavanju doseljenog stanovništva na posjedu. Određene prepreke povijesnoga konteksta, poput medicinske prijetnje koju su predstavljale malarične groznice, nije ni mogao predvidjeti pa stoga ni uspješno prevenirati demografske gubitke izazvane njima. Zato se može reći da su njegova nastojanja bila gotovo revolucionarno inventivna za Dalmaciju 18. stoljeća.

Vranska avantura usto je dovela i do napuštanja uspostavljene bioravnoteže vlažnoga močvarnog staništa. Intervencija čovjeka na sanaciji ratom devastiranih i zapuštenih kanala, isušivanju vranskog tla i generalnoj asanaciji močvara vodila je uspostavi nestabilnoga antropiziranog okoliša, koji je zahtijevao stalno održavanje i daljnje kultiviranje. Premda se i na ratna razaranja može gledati kao na čovjekom induciranu izmjenu okoliša, Borellijeva svjesna korekcija Vrane u cilju bonifikacije tla, povećanja uroda i poticanja samoodrživosti kod lokalnog stanovništva bila je i ekonomski vrlo oportuni potez. Premda je kratkoročno podbacio u rezultatima, dugoročno je projekt imao potencijala da potpuno promijeni ekonomsku sliku kraja.

Protomoderno iseljavanje s posjeda u svim smjerovima, izazvano ratnim razaranjima, ali i oskudicom, pod mletačkom su upravom pratili i doseljavanje obrađivača zemlje iz sjeverne Italije (Furlanije), lokalno seljenje unutar granica Mletačke Dalmacije te u većoj mjeri doseljavanje bukovičkih Morlaka s osmanskog serhata. Isušivanje je za doseljenike bio dodatni napor jer radovi na kanalima i kolonizacija stočarskih Morlaka nisu bili uravnoteženi i pomno isplanirani, niti su Morlaci bili dovedeni zbog melioracije. Primarno privučeni različitim povlasticama, oni su bili političko-ekonomski migranti, pa se isušivanje i migracije ne mogu neposredno povezati. $\mathrm{Ni}$ sesilizacija takva polunomadskog stanovništva nije dala očekivane rezultate, jer ono i dalje lokalno cirkulira umjesto da se veže uz dobivenu zemlju. Tek se manji dio duže zadržao na posjedu, ali se i obilato koristio fiskalnopravnim povlasticama za izbjegavanje obveza, pa je i u ekonomskom pogle- 
du kolonizacija podbacila. Demografski rast inicijalno je bio slab, ali zbog rasta životnog standarda i širenja obradive zemlje srednjoročno pokazuje pozitivne trenove.

Kako su razvoj i »napredak « donekle predstavljali ugrožavanje prirode same, upitno je i kako je ravnokotarski okoliš podnio čovjekovo zadiranje u prirodnu ravnotežu. Stoga smo preispitali ishode odnosno posljedice ranonovovjekovnog sraza ekonomije i ekologije. U tom smislu nagloga ekonomskog prosperiteta u kratkom roku nije ni moglo biti, jer se gospodarenje plodnom zemljom u okolnostima visoke ovisnosti o prirodnim ciklusima nije temeljilo na intenzivnoj zemljoradnji, već na ekstenzivnome (transhumantnom) stočarstvu. A ono ni srednjoročno nije ekonomski nadoknađivalo napore uložene $\mathrm{u}$ melioraciju tla. Kratkotrajne su posljedice također uključile obolijevanje radnika angažiranih na isušivanju terena, širenje bolesti, a potom i napuštanje iskrčene zemlje. Sela u unutrašnjosti, uključujući i Tinj, zbog same su melioracije inicijalno gubila stanovništvo, a usto postaju i demografski neproduktivna, odnosno obitelji izumiru. Uspjehu projekta nisu nimalo pridonijele ni malverzacije morlačkih vođa te neispunjena obećanja kojima su doseljenici privučeni na posjed. Upravo je kontekst pogranične nesigurnosti razvio otpor ratarstvu, a demografsko-ekonomsku situaciju dodatno je pogoršala prisutnost malaričnih groznica, kao i izostanak učinkovite prevencije i/ili liječenja. Ujedno je nova gospodarska eksploatacija predstavljala neracionalno upravljanje sredstvima, odnosno energijom i resursima.

Skupi pothvat isušivanja ostao je neiskorišten očuvanjem dominacije niskoprofitnoga i nezahtjevnog stočarenja, čime je disbalans ekonomske i okolišne eksploatacije vodio u ekonomsku neodrživost. Ipak, postupno uređenje zemlje otvara nove ekonomske mogućnosti, koje su svoju stvarnu realizaciju dosegnule tek nakon prokopa kanala Prosika u punom profilu za austrijske uprave u 19. stoljeću (Kos, 1971: 496). Srednjoročno je melioracija Vrane završila napuštanjem projekta i financijskim neuspjehom, premda zahvaljujući slabome demografskom rastu životni standard raste.

Intenzivno antropizirani okoliš iziskivao je kontinuirano održavanje i sve više ljudske intervencije u prirodu. Daljnja eradikacija malarije i stvaranje velikih intenzivnih poljoprivrednih dobara u 20. stoljeću naglašavaju dugoročne učinke Borellijevoga melioracijskog pothvata. ${ }^{24}$ Iskorjenjivanjem

24 Pa ipak, nepobitan je, pa makar i neizravan, današnji utjecaj klimatskih promjena poput globalnog zatopljenja na zdravlje ljudi. Ono je dovelo do širenja areala staništa komarca malaričara izvan dosad tradicionalnih staništa toga kukca. Jedna studija pokazuje da je čak 445 milijuna ljudi izloženo riziku od malarije svake godine u Africi i da taj rizik dovodi do više od 1,3 milijuna smrti od malarije godišnje (Barnett i Webber, 2010: 12). 
močvarnih groznica te dobivanjem većih površina plodnoga, a javno-zdravstveno "sigurnoga « tla stanovništvo se zadržava u kotarskim selima te se bilježi intenzivniji demografski rast. Zbog uzgoja intenzivnijih gospodarskih kultura i produktivnost na Vrani znatnije raste. Ta su dobra, poput Državnoga poljoprivrednog imanja Vrana u Jankolovici, Gospodarske stanice i rasadnika Sokoluša koji je intenzivirao uzgoj maraske, Uprave državne ergele Petrovo s Konjogojstvenim zavodom Vrana, koji se posvetio uzgoju lipicanaca, pa sve do peradarske farme i povrtnjaka Vrana d.o.o., u koju je povratnik Steve Bubalo uložio sredstva u 21. stoljeću, izgrađena na melioracijskim temeljima uređenja vranskog feuda u 18. stoljeću (Prtenjača, 1990: 677-696).

Sudar interesa ekonomije i ekologije u današnjem svijetu, u kojem se, posebno na razvijenom Zapadu, ogromna energija i resursi (npr. voda ili fosilna goriva) troše za neadekvatno niske (i skupe) rezultate poljoprivredne proizvodnje, znakovit je, iako je neusporediv sa stanjem u 18. stoljeću. Upravo je stoga kuriozitet uspjeha vranskih melioracija veći, kao i činjenica da su tadašnja niska razina produktivnosti i visoka razina ovisnosti ravnokotarskoga gospodarstva o prirodnim ciklusima bile dugoročno znatno održivije za samu prirodu. Danas je u istoj koliziji priroda uvijek na gubitku, dok se čovjek prije svega najčešće skrbi za kratkoročne ekonomske rezultate. Stoga otimanje prirodi Vranskog jezera i okolnih blata i njihov "povratak « čovjeku te uviđanje potrebe za kontinuiranim održavanjem već tada uspostavljaju novu ravnotežu ekonomije i okoliša. Melioracijom izmijenjen antropogenizirani izgled i funkcioniranje okoliša postaju u 18. stoljeću "prirodni «, odnosno ekološki održivi, a usto i ekonomski održivi za lokalne stanovnike, i to ne samo kratkoročno. Takvo napredno promišljanje prostora te balansiranje ekologije i ekonomije izraženo kroz ranonovovjekovnu vransku melioraciju rijetko susrećemo čak i u suvremenom svijetu.

\section{LITERATURA}

Bara, M. i Lajić, I. (2009). Prisilne, iznuđene i organizirane migracije u etnodemografskom oblikovanju Hrvatske: primjer Slavonije, Migracijske i etničke teme, 25 (4): 337-362.

Baras, F. (1977). Iz memoara maršala Marmonta. Split: Čakavski sabor.

Barnett, J. i Webber, M. (2010). Accommodating Migration to Promote Adaptation to Climate Change, u: Commission on Climate Change and Development. Stockholm: The World Bank (Policy Research Working Paper, 5270), https://openknowledge.worldbank. org/bitstream/handle/10986/3757/WPS5270.pdf (12. 09. 2014.). 
Božić-Bužančić, D. (1995). Južna Hrvatska u europskom fiziokratskom pokretu. Pokret za obnovu gospodarstva, gospodarske Akademije, ogledni vrtovi i poljodjelske škole druge polovice XVIII. stoljeća i početka XIX. stoljeća. Split: Povijesni arhiv u Splitu - Zavod za hrvatsku povijest Filozofskog fakulteta u Zagrebu - Književni krug.

Braudel, F. (1990). Civilizacije kroz povijest. Zagreb: Globus.

Čolak, N. (1957). Spis Andrije Borellija o uređenju Dalmacije krajem XVIII stoljeća, Mogućnosti, 4 (5): 397-401, (6): 499-510.

Delort, R. i Walter, F. (2002). Povijest europskog okoliša. Zagreb: Barbat.

de Vries, B. i Goudsblom, J. (ur.) (2003). Mappae Mundi Humans and their Habitats in a Long-Term Socio-Ecological Perspective: Myths, Maps and Models. Amsterdam: Amsterdam University Press, doi: https://doi.org/10.5117/9789053565353

Diamond, J. (2005). Collapse - How Societies Choose to Fail or Succed. London: Penguin Books.

Hafizović, F. (2016). Popis sela i zemlje sandžaka Krka, Klis i Hercegovina, oslobođenih od Mletačke Republike 1701. godine. Zagreb - Sarajevo: SDK Prosvjeta - Centar za komparativnohistorijske i interkulturne studije Filozofskog fakulteta Sveučilišta u Zagrebu- Orijentalni institut u Sarajevu.

Hekman, F. (1971). Melioracija Vranskog jezera. Vodoprivredna problematika vranskog područja, Radovi Instituta JAZU u Zadru, 18: 469-476.

Heršak, E. (2005). Drevne seobe: prapovijest i rani vijek. Zagreb: Školska knjiga.

Juran, K. (2005). Kad i u kojim povijesnim okolnostima Murterani i Betinjani dolaze na Kornate?, Povijesni prilozi, 28: 135-151.

Jurić, R. (1990). Srednjovjekovni spomenici na biogradskom području, u: Š. Batović (ur.). Biograd i njegova okolica u prošlosti: zbornik radova sa znanstvenog skupa održanog u Biogradu od 11. do 13. studenoga 1988. godine. Zadar - Biograd: Zavod za povijesne znanosti Filozofskoga fakulteta - SIZ kulture općine, 279-318.

Kolanović, J. (1971). Vrana i templari, Radovi Instituta JAZU u Zadru, 18: 207-226.

Kos, L. (1971). Pašmanski kanal - njegova uloga i značaj za Vranu, Radovi Instituta JAZU u Zadru, 18: 477-502.

Kulušić, S. (1959). Vransko polje, Geografski glasnik, 21 (1): 91-102.

Mayhew, T. (2008). Dalmatia between Ottoman and Venetian Rule. Contado Di Zara, 16451718. Rim: Viella.

McNeill, J. (2003). Observations on the Nature and Culture of Environmental History, History and Theory, 42 (4): 5-43, doi: https://doi.org/10.1046/j.1468-2303.2003.00255.x

Mesić, M. (2002). Međunarodne migracije: tokovi i teorije. Zagreb: Filozofski fakultet Zavod za sociologiju.

Mlinarić, D. (2004). Mal'aria i socio-migracijska kretanja u sjevernoj Dalmaciji u 18. stoljeću. (doktorska disertacija). Zagreb: Filozofski fakultet Sveučilišta u Zagrebu.

Mlinarić, D. (2006a). Les pratiques de guerison en Dalmatie du Nord a l'epoque moderne (XVIe-XVIIIe siecles): medecine populaire versus medecine officielle, u: P. Boulhold, F. Gaide i M. Loubet (ur.). Guerison du corps et de l'aime: approches pluridisciplinaires. Marseille: Universite de Provence, 311-329.

Mlinarić, D. (2006b). Uloga države u prevenciji i sanaciji lošeg utjecaja bolesti na gospodarstvo sjeverne Dalmacije u 18. stoljeću, Ekonomska i ekohistorija: časopis za gospodarsku povijest i povijest okoliša, 2: 39-54. 
Nedved, B. (1990). Biogradski kraj u rimsko doba, u: Š. Batović (ur.). Biograd i njegova okolica u prošlosti: zbornik radova sa znanstvenog skupa održanog u Biogradu od 11. do 13. studenoga 1988. godine. Zadar - Biograd: Zavod za povijesne znanosti Filozofskoga fakulteta - SIZ kulture općine, 213-246.

Nežić, E. (1939). Prilog poznavanju problema sjeverne Dalmacije, Časopis za vodnu, plinsku, sanitarnu i municipalnu tehniku, s prilogom za civilnu zaštitu, 5 (11-12): 501-511.

Obad, S. (1990). Prilike u Biogradu i okolici u prvoj polovici 19. stoljeća, u: Š. Batović (ur.). Biograd i njegova okolica u prošlosti: zbornik radova sa znanstvenog skupa održanog u Biogradu od 11. do 13. studenoga 1988. godine. Zadar - Biograd: Zavod za povijesne znanosti Filozofskoga fakulteta - SIZ kulture općine, 465-476.

Peričić, Š. (1971). Vranski feud i obitelj Borelli, Radovi Instituta JAZU u Zadru, 18: 389-411.

Pisani, P. (1893). La Dalmatie de 1797-1815. Pariz: Macon.

Prtenjača, V. (1990). Noviji rezultati RO Vrana i pravci razvoja poljoprivrede biogradskog područja, u: Š. Batović (ur.). Biograd i njegova okolica u prošlosti: zbornik radova sa znanstvenog skupa održanog u Biogradu od 11. do 13. studenoga 1988. godine. Zadar Biograd: Zavod za povijesne znanosti Filozofskoga fakulteta - SIZ kulture općine, 677-696.

Rimac, M. i Mladineo, G. (2009). Zadarsko okružje na mletačkom katastru iz 1709. godine, Prvi dio: Donji kotar. Zadar: Državni arhiv u Zadru.

Spaho, F. Dž. (1990). Vrana u turskoj vlasti, u: Š. Batović (ur.). Biograd i njegova okolica u prošlosti: zbornik radova sa znanstvenog skupa održanog u Biogradu od 11. do 13. studenoga 1988. godine. Zadar - Biograd: Zavod za povijesne znanosti Filozofskoga fakulteta SIZ kulture općine, 431-436.

Stanojević, G. (2004). Priručnik o vojnim krajinama u Dalmaciji iz 1783, prijevod u: D. Roksandić. Etnos, konfesija, tolerancija. Zagreb: Srpsko kulturno društvo »Prosvjeta«, 158-186.

Traljić, M. S. (1971). Vrana i njezini gospodari u doba turske vladavine, Radovi Instituta JAZU u Zadru, 18: 343-378.

\section{IZVORI}

Državni arhiv u Zadru

HR-DAZD, Spisi generalnih providura (SGP), Alvise Mocenigo, kut. II

HR-DAZD, SGP, Girolamo M. Balbi, kut. I

HR-DAZD, SGP, Alvise Contarini, kut. I i II

HR-DAZD, SGP, Francesco Diedo, kut. I i II

HR-DAZD, Stampe

HR-DAZD-382, Mletački katastri Dalmacije 17. i 18. stoljeća, kut. 68

HR-DAZD-383, Kartografska zbirka, inv. br. 94/A

HR-DAZD-348, Obitelj Borelli-Galbiani (OBG) (svežnjevi 1, 2, 3, 4, 6, 60, 61, 96, 98)

Nacionalna i sveučilišna knjižnica u Zagrebu

NSK, Zbirka starih karata i atlasa, SJ-Z-XVIII-18

Znanstvena knjižnica u Zadru

ZKZD, Manuscritti, br. 16530, Ms. 459.

ZKZD, Feudi in Dalmazia sotto il governo veneto, Ms. 110 


\title{
The Early Modern Land Reclamation, Protomodern Migration and Economic Development of the Feudal Estate of Vrana
}

\author{
Dubravka Mlinarić, Drago Župarić-lljić
}

\section{SUMMARY}

In the paper the authors are focused on local and trans-border migration processes in Northern Dalmatia and their influence on the economic and demographic development of the Vrana feudal estate during the $17^{\text {th }}$ and $18^{\text {th }}$ century. The research was based on the complex and qualitative analysis of demographic, economical, confessional and cartographic archival sources, followed by the correlation of existing secondary literature research (desk-study analysis). The primary scientific goal was to determine how the land reclamation and corresponding protomodern migrations, which had occurred prior the statistical period of migration registration, have changed and influenced further economic and environmental development of this particular hinterland of the Dalmatian area. The change of the lowland marshy borderlands was investigated within the frames of its physical ambience, geo-strategic position, and its communication, commercial and migratory potential, within the interdisciplinary framework and discourse of ecohistory and environmental studies methodology and approach.

In addition, this paper tends to discuss whether the Borelli family's private venture of investing in land reclamation was an economic success or rather an adventurous experiment since they failed to keep the immigrants colonized from Bukovica in permanent settlements. After getting the Vrana estate as a feudal possession in 1752, these Italian family members undertook a huge action of marshland and land reclamation in order to re-evaluate and redefine land use in the area that was once a prosperous Roman barn field, which provided food for a much larger population. Consequently, these newly gained lands were used by the state, along with some other tax and administrative benefits, to attract agrarian labour force. After drying the Vrana moors and marshes, damp soil improved in quality and the excess water was taken away, especially after the trenching of main and collateral ditches and a huge canal of Prosika, which connected the Lake Vrana with the Adriatic Sea, and the immigration has continued.

Considering the motives of these protomodern migrations as an interplay of intertwined migration factors, some typology of the most common patterns of spatial mobility has been discovered, including the patterns, shapes, directions and intensity of these migration lines. They included not only the war and post-war emigration from the estate, but also the immigration of Morlachs from the hilly area of Bukovica or even across the Ottoman borders in the hinterland, and transmigration, as well as family-related local migration, and seasonal shepherd (transhumant) migration (circulation) in the area. A specific "transborder" migration was a type of colonized compelled immigration of peasants from northern Italy (Furlania) to Northern (Venetian) Dalmatia as a working contingent of people, along with rare and occasional migrants of Italian nobility who conducted, directed and financed the Vrana reclamation projects (e.g. the Borelli from Bologna). 
The case study of migration network in the village of Tinj, besides the majority of settlers from the north-western area of Bukovica, has also revealed the immigrants from Primorje and even from the islands of Zadar archipelago coming to the Vrana estate. Some of them also helped in the drainage projects. New contingents of "healthy highlander Morlachs" from Bukovica were continuously invited, since they were perceived as more resistant to marshland fevers and likely to endure malaria-like diseases, which had significantly diminished the economic productivity and demographic potential of population in lowland areas. This local migration of Morlachs resulted in their engagement in reclamation as an additional task to their existing role in defense of Acquisto Nuovo and Acquisto Nuovissimo (Venetian hinterland) against eventual Ottoman Reconquista. During the period of destructive Anti-Ottoman wars in Kotari, the geostrategic relevance of this particular feudal estate's borderland position on the edges of various states, economic systems and cultures was of the utmost importance.

On the other hand, its liminal position as the Venetian overseas territory minimized the central state support and care in various kinds of perils. Hence, colonized immigration did not have ecological character although new settlers changed the landscape of Kotari. New and intensive agricultural (farmer) exploitation failed to upgrade economy since the prevailing sheep-breeding in highly fertile land represented the economic irrational land use. Demographic and economic development reflected the devastating results of anti-Ottoman early modern wars, followed by the environmental requirements and pressure of the Venetians. Getting in between the environmental interventions aiming to reach higher economic standards, the feudal estate happened to be radically changed by the reclamation. It was, for the first time since the Roman era, an extraordinary intervention into natural balance of the lowland ecosystem.

The results of these early modern collisions of economic and environmental interests in Vrana in the short period significantly differed in quality and direction of its development in comparison to the long-term perspective. On the one hand, especially in the middle and long-term perspective, it showed elements of economic and demographic success, with a reasonable potential to fully reshape the demographic potential of the area. Quite contrary, the short time scale was, if not a complete failure, then at least an uncertain and adventurous experiment. In spite of that qualification, Francesco Borelli's reclamation of marshlands was a hydro-technical step forward, totally in accordance to similar European intellectual (physiocratic) movements and projects, reflecting the spread of comparable ideas to the eastern corners of eastern Adriatic territories under European rulers. However, the Borelli family also encountered serious obstacles in implementing innovative plans, such as continued political and military insecurity on the borderland(s), including also the Ottoman part (serhat).

Besides the fiscal and other privileges that were promised to Morlachs in order to attract them to the deserted land by the former owners, Borelli's innovative and economic capacities were further jeopardized by the lack of solid political (and organizational) support of Venetian administration. They even did not succeed in settling the colonized immigrant population more permanently into the nine villages of the Vrana estate, partly due to additional irrigation work Morlachs had to complete, but also due to disadvantageous demographic threat represented by the unknown medical dangers such as malarial fevers. Since these phenomena were unknown and undiagnosed (prior to the mid-19 ${ }^{\text {th }}$ century) the adequate treatment or prevention 
could not be applied. In spite of all unfavourable factors or even failure to decrease circulation of local population in the area, these projects can be defined as revolutionary inventive for the $18^{\text {th }}$ century, especially for Dalmatian periphery. Among other ecological results, human intervention into drainage of devastated and abandoned water sources and channels led to formation of highly anthropogenically shaped landscape, which was crucially dependent on constant cultivation and protection. Moreover, expensive reclamation projects were not fully and properly exploited, since the Ottoman presence in the vicinity and total insecurity prevented and even repulsed Morlach shepherds from changing their low profit shepherd economy to high profit intensive agricultural land use. Such a misbalance of economic and environmental interests tended to reverse Borelli's efforts and new economic exploitation kept the economy on unsustainable levels, detaining the irrational management of energy, resources and land.

On the other hand, the improved soil and drained land allowed a slow increase of crop each year, ensuring higher self-provision of the local population. Demographic growth was gradual and endangered by malarial fevers. They significantly reduced the number of people, especially children, but also limited economic productivity of those who survived. However, life standard increased based also on the extension of arable lands. Intensive agricultural production with new cultures increased the productivity level. The collision of economic and environmental interests resulted especially in long-term improvements of the main trends since the early modern economy was highly dependent on natural cycles and not based on intensive agriculture, but rather on extensive transhumant cattle breeding, which could not effectively correspond to huge human/material investments into land reclamation, especially in a short time span. Gradually, the land improvement opened new economic possibilities, being fully exploited after the extending and widening of the Prosika canal, which had been finished during the Austrian rule in the $19^{\text {th }}$ century. The failure of the Borelli's project reflected in the abandoning of the works and bankruptcy of the count Francesco, but the reclamation results turned to be the base for economic/ demographic achievements in later centuries. The extinction of malarial fevers and the episodes of other diseases were followed by founding of huge farms in the $20^{\text {th }}$ century. By providing a significant areal of new fertile land which was safe from a sanitary perspective, the local population got the possibility to permanently settle the lowland Vrana villages and improve disadvantageous demographic trends.

By comparing incomparable, it is obvious that contrary to huge waist of energy and resources (e.g. of water and fossil fuels) in modern Western societies, a low level of agricultural production in Vrana and high dependence on natural principles have been ecologically and environmentally sustainable, especially in long-term perspective. The same collision of nature (environment) and economy today usually ends in short-term economic results and total neglecting of any other interest. Therefore, Vrana's reclamation represented, on the one hand, the abduction of moors and marshes, and their return to man, but on the other hand, an achievement of regained balance between economy and ecology. Such an equilibrium, as it was accomplished in the $18^{\text {th }}$ century by the Vrana reclamation, can be rarely met even today.

KEY WORDS: migrations, Early Modern period, land reclamation, environment, Northern Dalmatia, economic development, demographic development 